\title{
How Antonin Scalia Punched Down
}

by Peter Shane_http://washingtonmonthly.com/people/peter-shane//

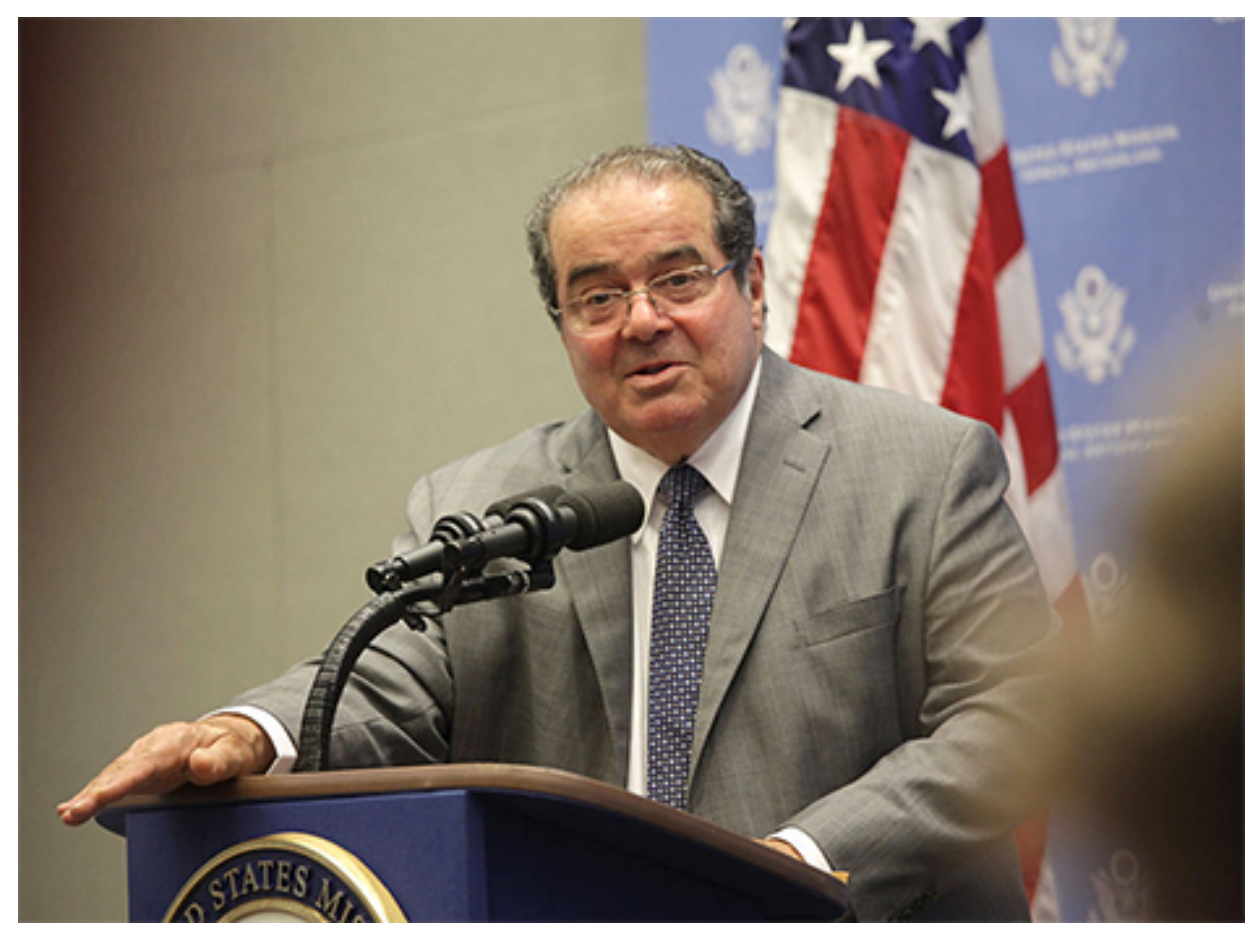

The encomiums bestowed upon the late Justice Antonin Scalia know no partisan limits. Tributes from conservatives have been earnest and effusive, untroubled, of course, by philosophical disagreement. But the homages that begin, "Although we agreed about nothing," have been no less heartfelt or expansive. Many across the ideological spectrum were privileged to experience Justice Scalia as a warm, generous, witty, charming, larger-than-life companion and mentor. 
In candor, these were not the qualities I encountered when I did see the justice up close. The worst of these moments occurred when he lectured at my law school on originalism, his favored approach to constitutional interpretation. One of his first questioners from the audience was an audibly nervous law student. She asked whether we might owe less allegiance to the precise views of our constitution's drafters and ratifiers, given that women, African-Americans, and Native Americans were excluded from those roles. Justice Scalia all but sneered in response, "Well, it's obvious you just don't believe in the Constitution!"

It's one thing to bare one's teeth to another justice or even to a combative law professor. To scoff sarcastically - and, one must add, nonsensically - at a nervous student just felt like bullying. We all have our worst moments, but witnessing that encounter inevitably complicated for me any future appreciation of the Antonin Scalia that even my liberal friends who knew him describe so earnestly.

My assessment of Justice Scalia on the court is likewise ambivalent. As late as the 1980s, when Professor Scalia became Judge and then Justice Scalia, "originalism" in constitutional interpretation and "textualism" in statutory interpretation lived largely at the margins of contemporary legal thought. In uniting mostly right-wing politics with a vigorous theoretical defense of both methods, Scalia laid the cornerstone for an edifice of conservative legal thought that has had an incalculable impact on thirty years of American law. That edifice will frame constitutional advocacy both within and beyond the judiciary for many more decades.

Justice Scalia's work thus stands as an enormous institutional achievement, although driven, at least in my estimation, as much by the man's prose style and charisma as by the intrinsic merits of his ideas. His forcefulness, however, hugely enriched American law by provoking a far deeper and more serious engagement with interpretive theory, by both his advocates and detractors, than had been seen in the decades preceding his ascent. His engagement strengthened both sides.

At the same time, Justice Scalia routinely deployed his methods largely in service of bad causes. In cases on race and sex discrimination, the rights of gays and lesbians, the Eighth Amendment, voting rights, consumer rights, environmental law - pretty much every cause progressives have embraced since the New Deal - he voted the positions of a committed revanchist determined to turn back the political and jurisprudential clock.

Almost as bad, in both dissents and separate concurrences, Justice Scalia was famously prone to lace his analyses with scorn and ridicule for those with whom he disagreed. These were and are texts destined to be read by generations of lawyers and law students, as well as by the general public. They are regrettable 
not only in their lack of professionalism but because they no doubt help to legitimate a corrosive form of intellectual discourse which confuses contempt with reason, and which has become all too common.

Because Justice Scalia's career was so varied and substantial in its impact, there will be a vigorous cottage industry among law professors and legal historians assessing his intellectual and institutional legacy. There will be articles defending both his methods and the particular results to which his methods led them. Some of those papers may even offer stronger arguments than those Justice Scalia himself put forward in defense of his methods and results.

At the same time, there will be writings challenging Justice Scalia across the board, in some cases again, I am confident - deepening the critiques that emerged during his lifetime. There will be articles showing not only theoretical vulnerabilities in his methods, but also his inconsistencies in applying those methods - inconsistencies perhaps suggesting that the political desire for particular results sometimes overcame theoretical purity. This is a fault to which no judicial faction is immune.

Today, however, Justice Scalia has left me with two tasks. One, as always, as I teach constitutional law, is to help my students wrestle with Justice Scalia's ideas - to be able to see his positions in their most favorable, as well as their most vulnerable light and thus, I hope, to help my students advance as wellinformed, independent thinkers, reaching their own nuanced assessments of Justice Scalia's legacy. The second is to extend my heartfelt sympathies to those members of my own circle of friendship and acquaintance who were close to Justice Scalia and who have no doubt lost a treasured friend.

Peter Shane (http://washingtonmonthly.com/people/peter-shane/)

Peter Shane teaches constitutional law at the Ohio State University's Moritz College of Law and is the author of

Madison's Nightmare: How Executive Power Threatens American Democracy (http://www.amazon.com/madisonsnightmare-executive-threatens-democracy/dp/0226749398)

(University of Chicago Press 2009). 
(c) 2017 Washington Monthly. 